\title{
PEWNE UWAGI NA TEMAT MOŻLIWEJ FUNKCJI BEZPOŚREDNIEJ MIECZA BRĄZOWEGO Z GROBU NR 7429 Z CMENTARZYSKA CIAŁOPALNEGO KULTURY ŁUŻYCKIEJ W DOMASŁAWIU W ŚWIETLE ANALIZ TRASEOLOGICZNYCH
}

\author{
SOME REMARKS ON THE POTENTIAL METHOD OF USE OF A BRONZE \\ SWORD FROM GRAVE NO. 7429 FROM A LUSATIAN CULTURE CREMATION \\ CEMETERY IN DOMASŁAW IN THE LIGHT OF USE-WEAR ANALYSIS
}

\begin{abstract}
The specific relationship between weapon-form and mode of use has become a subject of intense research regarding the martial practices of past societies. In recent years the application of wear analysis to bronze offensive weapons has allowed us to define their function on the basis of recognizable damage. This paper aims to present results of use-wear analysis conducted on a unique bronze sword that was found in Domasław, Poland in a cremation cemetery belonging to Lusatian culture. The sword reveals a broad range of traces, ones which may be attributed to respective fighting techniques. Another goal of the present work is to partially fill the research void which presently exists concerning warfare as practiced by the Lusatian culture people, and to point out the necessity of carrying out further studies of this kind.
\end{abstract}

KEY WORDS: use-wear analysis, traceology, bronze sword, Lusatian culture, iron age warfare

Badania nad funkcją bezpośrednią mieczy kultury łużyckiej nie doczekały się dotychczas analiz innych niż próby wykazywania korelacji między konkretnymi cechami morfologicznymi uzbrojenia a preferowanym sposobem jego użytkowania (Fogel 1979, 77-78). Brak wykorzystania w nich narzędzi badawczych o bardziej empirycznym charakterze stanowi poważną lukę w rozważaniach nad wojskowością kultury łużyckiej. Zastosowanie traseologii w badaniach bronioznawczych, czyli metody polegającej na analizie śladów pozostałych na powierzchniach znalezisk archeologicznych, pozwoliło w ostatnich latach na uzyskanie szerszego spektrum informacji na temat technik walki uzbrojeniem zaczepnym w prehistorii i antyku. Szczególne znaczenie analiz traseologicznych dla archeologii konfliktu uwidacznia się z pewnością w przypadku badań przeprowadzonych przez K. Kristiansena, których przedmiotem były wykonane $\mathrm{z}$ brązu miecze przechowywane w Węgierskim Muzeum Narodowym. Wspomniany badacz rozpoznał na krawędziach datowanych na epokę brązu mieczy v-kształtne nacięcia wskazujące na kontakt głowni z krawędzią innego miecza, a także ślady ostrzenia, co pozwoliło nakreślić obraz broni w pełni funkcjonalnej 
w warunkach pola bitwy (Kristiansen 2002, 319-325). Zakwestionowanie poglądu głoszącego, że broń biała wykonana $\mathrm{z}$ brązu nie mogła być użytkowana jako efektywne narzędzie walki, pozwoliło na prowadzenie badań ukierunkowanych na lepsze zrozumienie funkcji brązowych mieczy. Ten swoisty przełom z pewnością wywarł niebagatelny wpływ na rosnącą rolę traseologii w badaniach nad pradziejowym uzbrojeniem zaczepnym. Różne rodzaje zaobserwowanych uszkodzeń skłoniły badaczy do stawiania pytań o ich dokładną genezę, a zaangażowanie metod $\mathrm{z}$ zakresu archeologii eksperymentalnej pozwoliło określić sytuacje, w których dane uszkodzenia mogły powstać, dostarczając tym samym narzędzi empirycznych pomagających w odtwarzaniu dawnych technik walki mieczem (Molloy 2016, 67-81). Celem artykułu jest zaprezentowanie wyników analiz traseologicznych brązowego miecza typu Büchenbach pochodzącego z cmentarzyska ciałopalnego kultury łużyckiej w Domasławiu, które mogą dostarczać pewnych przesłanek ku próbie określenia techniki walki, zgodnie z którą wykorzystywany był wspomniany element uzbrojenia.

Miecz odnaleziony został w komorze nr 7429. Jego długość wynosi $76,5 \mathrm{~cm}$. Posiada on poszerzoną sztabę do rękojeści o wymiarach 11 x 3-3,8 cm zakończoną pięciokątną płytką głowicową oraz umieszczone na rękojeści otwory na nity służące do przymocowania okładzin. Charakterystyczną cechą miecza jest liściowaty kształt głowni oraz obecność ricasso, czyli niezaostrzonego fragmentu głowni zlokalizowanego u jej nasady (Gediga et al. 2018, 138; Gediga, Józefowska 2018, 178). Niniejsza praca ma również na celu wskazanie użyteczności i potencjału tkwiącego $\mathrm{w}$ metodzie traseologicznej oraz zasygnalizowanie konieczności prowadzenia szeroko zakrojonych badań uzbrojenia kultury łużyckiej z jej wykorzystaniem. Próba udzielenia odpowiedzi na pytania dotyczące kwestii tak kluczowej dla archeologii konfliktu, jak wielopoziomowa relacja pomiędzy wojownikiem a jego uzbrojeniem zawsze wymaga wykorzystania wszystkich informacji, które uchwytne są w materiale archeologicznym. Stosunkowo często zachodzi również konieczność sięgnięcia po dane $\mathrm{z}$ zakresu dziedzin takich jak etnologia, historia czy antropologia i operowania nimi na zasadzie analogii. Choć przedmiotem dociekań w niniejszej pracy jest tylko jedna ze składowych wspomnianej wielopoziomowej relacji, a mianowicie potencjalna zależność pomiędzy cechami morfologicznym broni a preferowanym sposobem walki za jej pomocą, to z pewnością jej istnienie nie może zostać dowiedzione jedynie na drodze rozważań o charakterze czysto intuicyjnym. Na gruncie metodologii archeologicznej konieczne jest wyjście poza ramy typologii rozumianych jako systemy klasyfikacyjne służące przede wszystkim porządkowaniu znalezisk archeologicznych. W celu ustalenia, czy pewne cechy morfologiczne miecza determinowały technikę posługiwania się nim na polu bitwy, konieczne jest potraktowanie owych cech nie jako zmienne, których koincydencja tworzy jedynie jednostkę taksonomiczną w ramach typologii, lecz jako potencjalnie zamierzone rozwiązania technologiczne zastosowane w konkretnym celu. Przyjęcie takiego założenia metodologicznego zdaje się mieć swoje uzasadnienie w wynikach dotychczasowych badań z zakresu archeologii eksperymentalnej. Jako przykład mogą posłużyć tu badania brązowych mieczy egejskich, w przypadku których dokładne analizy ich cech morfologicznych wespół z zastosowaniem metod eksperymentalnych wykazały, że konkretne właściwości konstrukcyjne wspomnianych mieczy pozwalały posługiwać się nimi w określony sposób (Molloy 2010, 403-428). Choć w przypadku zabytku z Domasławia nie było możliwe przeprowadzenie eksperymentu pozwalającego zreplikować uszkodzenia zaobserwowane mikroskopowo, to zebrana w literaturze przedmiotu baza rozpoznanych i odtworzonych uszkodzeń okazała się na tyle obszerna, iż odnalezienie analogii było zadaniem jak najbardziej wykonalnym. Co więcej, pewnych wskazówek co do możliwej funkcji bezpośredniej domasławskiego miecza dostarczyła jego konstrukcja. Wydaje się, że szczególna cecha morfologiczna wspomnianego zabytku, jaką jest lekkie poszerzenie głowni blisko końca sztychu, mogła mieć znaczenie w kontekście preferowanego sposobu jego użytkowania. Taki zabieg konstrukcyjny powodował umiejscowienie środka ciężkości bliżej końca ostrza, a tym samym czynił miecz bardziej efektywnym podczas zadawania ciosów tnących niż pchnięć (Osgood 1998, 13), inaczej niż miało to miejsce w przypadku mieczy cechujących się przesunięciem środka ciężkości ku rękojeści, które były bardziej użyteczne przy zadawaniu pchnięć (Mödlinger 2007, 110).

Analizy brązowego miecza z cmentarzyska w Domasławiu zostały przeprowadzone przy pomocy mikroskopu cyfrowego, a zakres użytych powiększeń wahał się od 20 do $30 \mathrm{x}$. Bardzo dobry stan zachowania zabytku pozwolił na to, by analizom mogła zostać poddana zarówno strona $\mathrm{A}$, jak i strona $\mathrm{B}$. Bodaj najbardziej charakterystycznym typem uszkodzenia, które niezwykle często pojawia się na krawędziach brązowej broni białej, jest wcięcie v-kształtne oraz 
u-kształtne (Brandherm 2016, 27; Dolfini, Crellin 2016, 83; Horn, Karck 2019, 1-7; Molloy 2016, 75-77; O'Flaherty et al. 2016, 41-48). Miecz z Domasławia nie stanowi pod tym względem wyjątku. Ślad, który powinien zostać zaklasyfikowany jako jeden z wymienionych typów, został zaobserwowany na krawędzi głowni w znacznej odległości od rękojeści (ryc. 1), podobnie jak reszta uszkodzeń opisana w niniejszym artykule. Trudność z dokładnym określeniem rodzaju wspomnianego wcięcia wynika z jego niejednoznacznego kształtu. Choć zaokrąglone dno jest cechą charakterystyczną wcięć u-kształtnych, to profil śladu ma raczej kształt litery „v”. Jako przyczynę powstania śladów v-kształtnych wskazuje się zwykle krótkotrwały, prostopadły kontakt z ostrzem innej broni białej, który został stosunkowo szybko przerwany poprzez odparowanie ciosu (Higgins 2010, 197; Molloy 2016, 75). Geneza wcięć u-kształtnych zazwyczaj łączona jest z wystąpieniem dłużej trwającego kontaktu pomiędzy dwoma ostrzami połączonego często z wykonaniem ruchu skrętnego (Higgins 2010, 203; Molloy 2016, 75). Należy w tym miejscu podkreślić, iż niezależnie od tego, jak dokładnie wyglądała sytuacja, w wyniku której powstał omawiany ślad, to z pewnością przyczyny jego obecności na krawędzi domasławskiego miecza należy upatrywać w kontakcie z inną twardą krawędzią, prawdopodobnie ostrzem innej broni. Wyniki przeprowadzonych dotychczas badań wskazują, iż kształt wcięcia jest wypadkową działania wielu czynników, takich jak rodzaj użytego uzbrojenia, siła i kąt uderzenia, a nawet rodzaj chwytu zastosowanego do trzymania oręża $\mathrm{w}$ trakcie walki (O'Flaherty et al. 2016, 41-48). Należy zatem zaakceptować fakt, iż w przypadku dwóch najbardziej powszechnych rodzajów wcięć, jakie spotykane są na krawędziach mieczy, możemy mieć do czynienia z nie zawsze dającą się precyzyjnie określić przyczyną ich powstania. Niemniej jednak możemy bezpiecznie założyć, iż zarówno wcięcia v-kształtne, jak i wcięcia u-kształtne, są praktycznie zawsze rezultatem intencjonalnego kontaktu dwóch ostrzy, do którego doszło poprzez zadanie lub odparowanie ciosu. W okolicy wspomnianego wcięcia nie zaobserwowano obecności zewnętrznego wygięcia małych partii krawędzi głowni, które mogłyby dodatkowo wskazywać na powstanie uszkodzenia poprzez kontakt z twardą i ostrą krawędzią. Niemniej jednak z pewnością nie można wykluczyć, iż potencjalna deformacja plastyczna mogła ulec wykruszeniu lub zeszlifowaniu w trakcie naprawy. W okolicach omawianego uszkodzenia można dostrzec rysy znajdujące się pod patyną i produktami korozji, powstałe prawdopodobnie w wyniku gładzenia powierzchni głowni. Obecność podobnych śladów w okolicach uszkodzeń krawędzi została już stwierdzona w przypadku innych elementów brązowego uzbrojenia zaczepnego (Horn, Holstein von 2017, 93). Warto zauważyć, że obserwacje wspomnianego śladu przeprowadzone z drugiej strony głowni (ryc. 2) nie

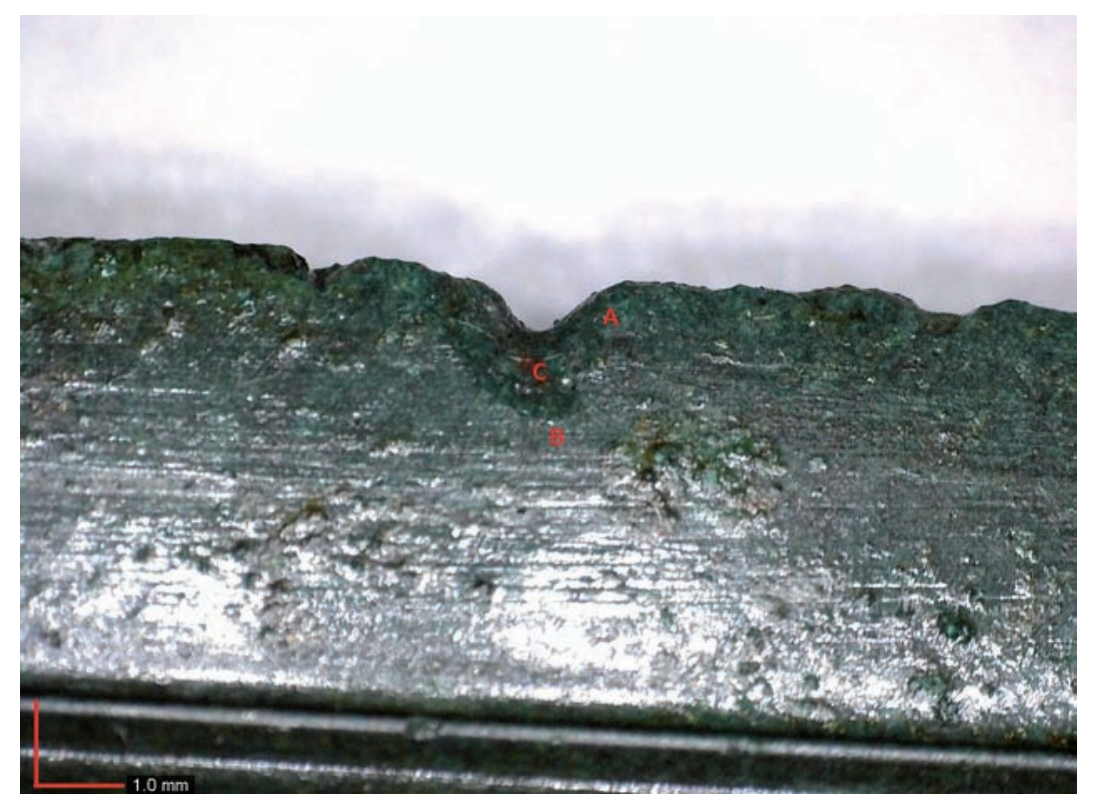

Ryc. 1. A - wcięcie v lub u-kształtne; B - rysy znajdujące się pod patyną i śladami korozji; $\mathrm{C}$ - niecka w okolicy wcięcia v-kształtnego. Powiększenie 30-krotne

Fig. 1. A - v or u-shaped notch; B - fissures under patina and corrosion products; $\mathrm{C}$ - basin in the area of v-shaped notch. Magnification: $30 \mathrm{x}$ 


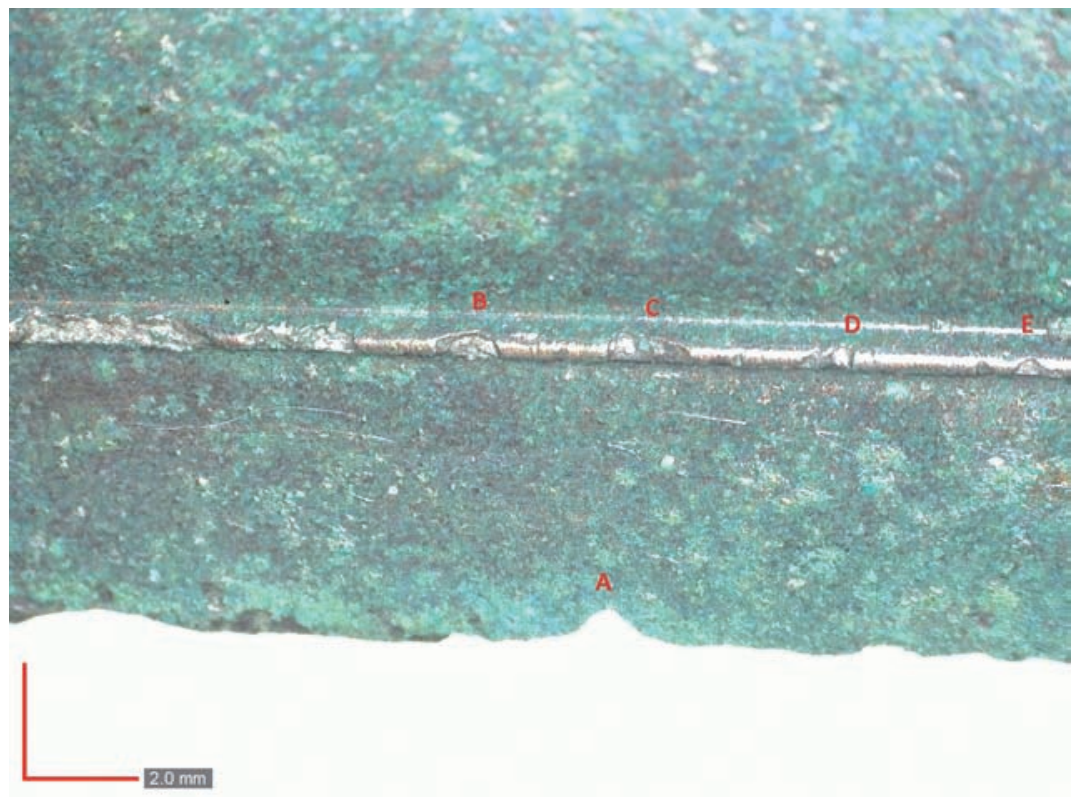

Ryc. 2. A - wcięcie v lub u-kształtne widoczne $\mathrm{z}$ drugiej strony. Brak widocznych rys w jego okolicy;

B, C, D, E - nacięcia spowodowane zablokowaniem ciosu płazem miecza. Powiększenie 20-krotne

Fig. 2. A $-\mathrm{v}$ or $\mathrm{u}$-shaped notch visible from the other side. No visible fissures in its area;

$\mathrm{B}, \mathrm{C}, \mathrm{D}, \mathrm{E}$ - notches caused by blocking blows with the sword flat. Magnification: $20 \mathrm{x}$

wykazały obecności podobnych rys w jego okolicy. Fakt ten może stanowić dodatkowy argument przemawiający za tym, iż występowanie rys w sąsiedztwie uszkodzenia należy wiązać z naprawą mającą na celu usunięcie wygiętego fragmentu głowni. W rejonie wcięcia, tuż poniżej opisywanego śladu, stwierdzono także obecność płytkiej niecki, która powstała najprawdopodobniej w wyniku usunięcia materiału, który uległ przemieszczeniu w wyniku kontaktu ostrza miecza z inną ostrą krawędzią. Obecność uszkodzeń wskazujących na czysto militarną funkcję analizowanego miecza, a także śladów będących najpewniej świadectwem dokonywanych na nim napraw, staje się niezwykle interesująca $\mathrm{w}$ obliczu informacji uzyskanych dzięki badaniom metaloznawczym interesującego nas artefaktu. Wykazały one, iż miecz został wykonany z brązu cynowego $(7,51 \% \mathrm{Sn}) \mathrm{z}$ dodatkiem ołowiu $(0,91 \% \mathrm{~Pb})$, który odznaczał się stosunkowo dużą wytrzymałością i plastycznością, ale za to niską twardością (Gediga et al. 2018, 150-154). Pod tym względem zabytek z Domasławia nie odbiega znacząco od innych brązowych mieczy z obszaru Europy Środkowej datowanych na późną epokę brązu i okres halsztacki, których militarna funkcjonalność została potwierdzona poprzez analizy metalograficzne i traseologiczne (Mödlinger 2016, 153-154). Najprawdopodobniej domasławski zabytek wpisywał się w ogólny trend produkcji mieczy, których parametry techniczne czyniły je jednocześnie funkcjonalnym uzbrojeniem ofensywnym, jak również obiektami stosunkowo łatwo poddającymi się różnym rodzajom elaboracji w procesie produkcji, a później ewentualnym zabiegom naprawczym. Niezwykle interesujące uszkodzenia mające postać rzędów niewielkich nacięć zostały rozpoznane na żebrach tworzących strudziny miecza (ryc. 2; ryc. 3). Przeprowadzone dotychczas analizy dowodzą, iż taki typ śladu jest wynikiem zablokowania ciosu przy pomocy płazu miecza (Gentile, Gijn van 2019, 137). Kolejnym typem śladu, który został zaobserwowany na krawędzi miecza z Domasławia jest wcięcie o szerszym, bardziej zaokrąglonym kształcie (ryc. 3), które jednoznacznie może zostać zaklasyfikowane jako wcięcie u-kształtne. Jak już wcześniej wspomniano, jako przyczynę jego powstania często wskazuje się dłużej trwający kontakt pomiędzy dwoma ostrzami połączony często z wykonaniem ruchu skrętnego. Obok nich widoczne są również dużo płytsze nacięcia, których powstanie mogło być rezultatem ciosów zadanych z mniejszą siłą (Higgins 2010, 203; Molloy 2016, 75). Poddany analizie zabytek nosi również ślady nieco mniej transparentnych uszkodzeń. Zaliczyć do nich można serię bardzo płytkich wgłębień tworzących wrażenie pofalowania krawędzi miecza (ryc. 3). Uszkodzenia przyjmujące taką formę powstają w sytuacji, gdy dochodzi do zetknięcia się dwóch ostrzy mieczy pod relatywnie 

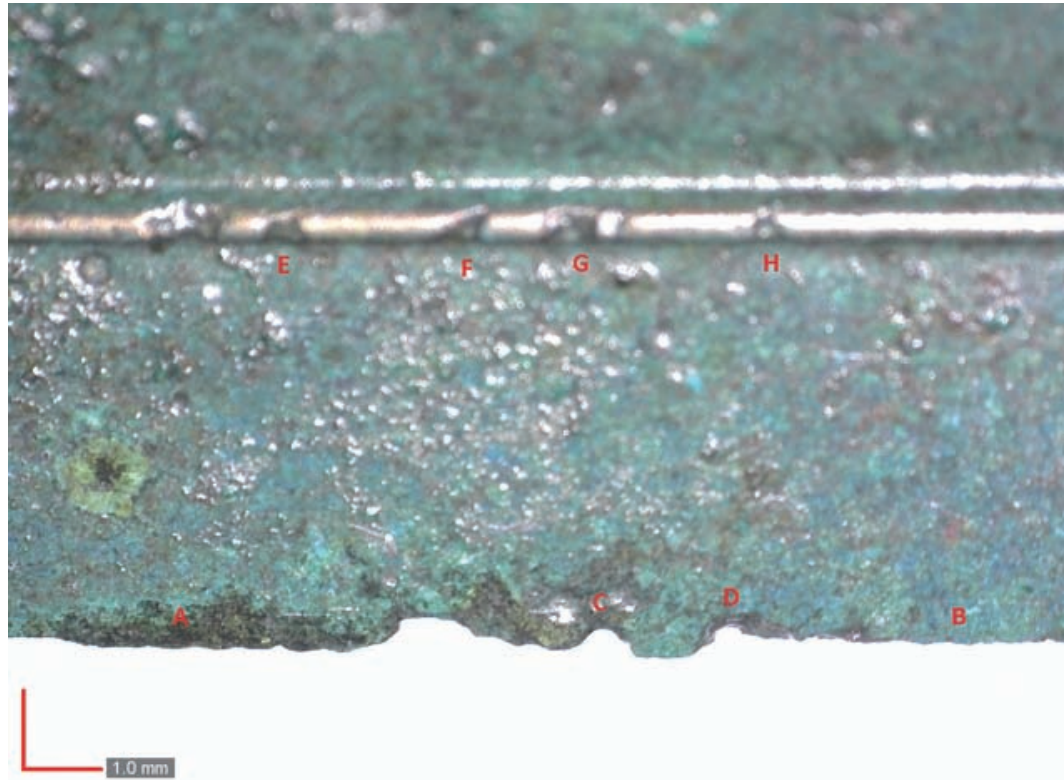

Ryc. 3. A, B - pofalowanie krawędzi powstałe w wyniku ześlizgnięcia się krawędzi innego ostrza; C, D - wcięcia u-kształtne; F-H - nacięcia spowodowane zablokowaniem ciosu płazem miecza. Powiększenie 30-krotne

Fig. 3. A, B - edge waving caused by slipping of the edge of another blade; C, D-U-shaped notches; $\mathrm{F}-\mathrm{H}$ - notches caused by blocking blows with the sword flat, Magnification: $30 \mathrm{x}$.
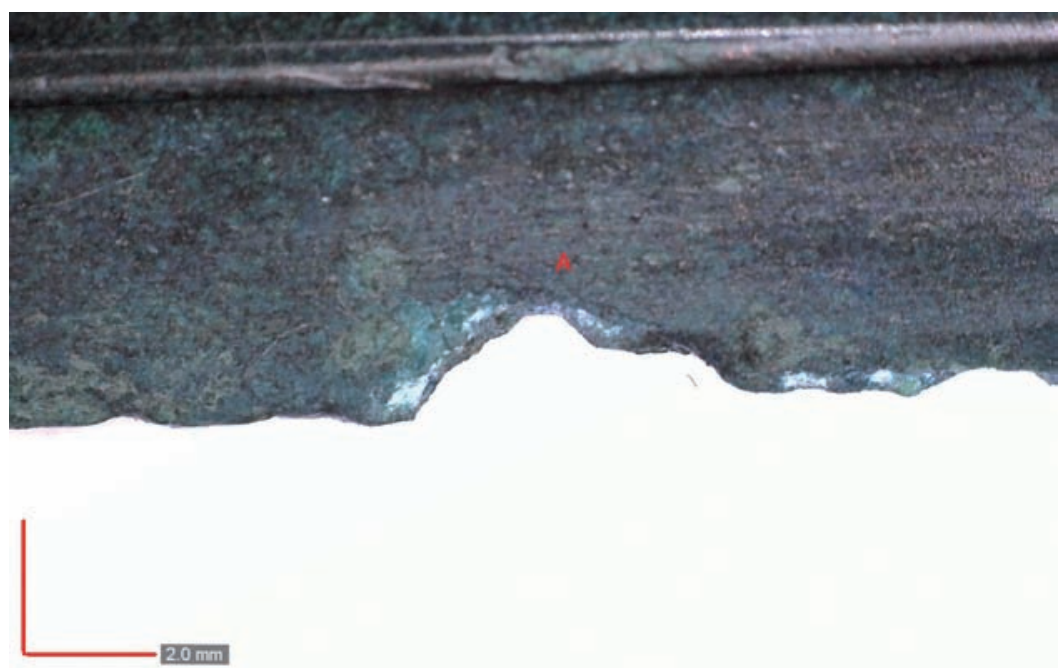

Ryc. 4. A - asymetryczny ubytek na krawędzi miecza. Powiększenie 25-krotne

Fig. 4. A - asymmetrical indentation on the sword edge. Magnification: $25 \mathrm{x}$

małym kątem, a następnie ześlizgnięcia się jednego z ostrzy po krawędzi drugiego, odbijając się przy tym od niej kilkukrotnie (Gentile, Gijn van 2019, 137). Analizy traseologiczne wspomnianego artefaktu wykazały również obecność dużo większego i mniej regularnego ubytku (ryc. 4), w przypadku którego wskazanie jego możliwej genezy jest zadaniem znacznie trudniejszym. Wiele ubytków znacznych partii materiału rozpoznanych na innych elementach uzbrojenia brązowego może być wynikiem działania proce- su postdepozycyjnego. Należy również przypuszczać, iż za powstanie części z nich odpowiada użytkowanie broni na polu walki (Brandherm 2016, 27). Stosunkowo duże i asymetryczne ubytki mogą być rezultatem płynnego odparowania ciosu bez zastosowania twardego bloku (Gentile, Gijn van 2019, 134-137). Zapewne nie można również wykluczyć możliwości, iż wspomniany ślad obecny na krawędzi domasławskiego miecza powstał $\mathrm{w}$ wyniku uderzenia zadanego $\mathrm{z}$ dużą siłą, a następnie uległ wtórnemu uszkodzeniu 


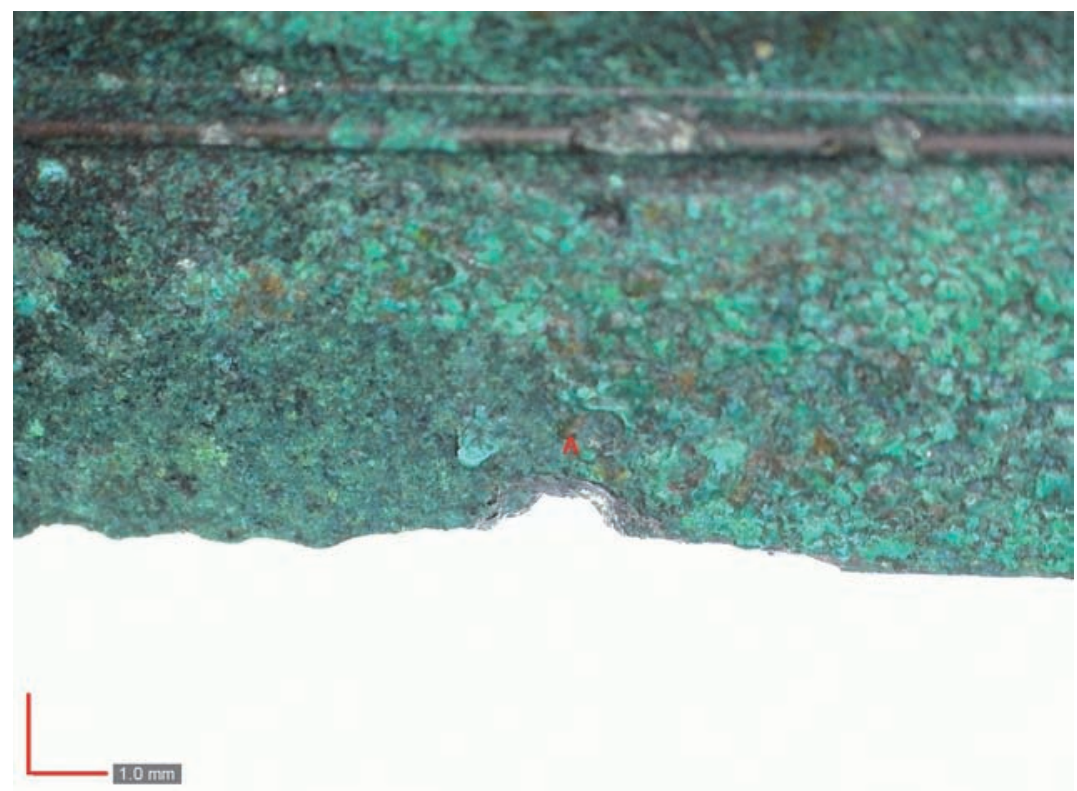

Ryc. 5. A - asymetryczne wcięcie otoczone przez partię przemieszczonego materiału. Powiększenie 30-krotne Fig. 5. A - Asymmetrical notch surrounded by a piece of displaced material. Magnification: $30 \mathrm{x}$

w wyniku dalszego użytkowania lub postępującego procesu postdepozycyjnego. Obserwacje mikroskopowe wykazały również obecność innego asymetrycznego wcięcia na krawędzi miecza, które otoczone jest przez partię materiału przemieszczonego w stronę środkowej części głowni (ryc. 5). Mechanizm powstawania uszkodzenia takiego typu jest taki sam jak w przypadku wcięć v-ksztaltnych oraz u-kształtnych, $\mathrm{z}$ tą jednak różnicą, iż mały fragment materiału tworzącego głownię miecza przemieścił się pod wpływem siły uderzania, tworząc zgrubienie w okolicy powstałego ubytku (Gentile, Gijn van 2019, 136-137; Gutiérrez Sáez, Lerma 2015, 180). Analizy traseologiczne brązowego miecza z Domasławia wykazały obecność uszkodzeń powstałych w wyniku szerokiego spektrum sposobów wykorzystania broni w trakcie fechtunku. Ślady rozpoznane na wspomnianym zabytku zdają się wskazywać, że był on wykorzystywany przede wszystkim jako broń sieczna. Fakt ten pokrywa się z dotychczasowymi założeniami dotyczącymi mieczy kultury łużyckiej, zgodnie z którymi liściowaty kształt głowni miał predysponować broń do zadawania głównie ciosów tnących (Fogel 1979, 77). W kontekście tych ustaleń nie bez znaczenia wydaje się być obecność ricasso oraz stosunkowo krótka rękojeść miecza z domasławskiej nekropolii łużyckiej. W trakcie walki cztery palce mogły spoczywać na rękojeści, zaś palec wskazujący mógł znajdować się na ricasso, będąc częściowo owiniętym wokół niego. Takie ułożenie dłoni na rękojeści pozwala- łoby ułożyć trajektorię ostrza głowni zgodnie $\mathrm{z}$ naturalną trajektorią ramienia poruszającego się podczas zadawania ciosu (Molloy 2007, 108). Takie rozwiązanie dawało możliwość lepszej kontroli głowni miecza, co z kolei musiało być szczególnie istotne w przypadku zadawania cięć. Możliwość zwiększenia zasięgu chwytu nieco poza jelec niwelowała również w pewnym stopniu skutki ulokowania środka ciężkości miecza bliżej końca sztychu, co mogło skutkować większą precyzją również przy ewentualnym zadawaniu pchnięć. Choć broń biała posiada często charakter wielofunkcyjny (Clements 2007, 168-176), to zastosowanie takiego rozwiązania konstrukcyjnego stanowi niewatpliwie kolejny argument za tym, że podstawową funkcją bezpośrednią miecza z Domasławia było zadawanie ciosów siecznych. Szczegółowe studia nad uzbrojeniem pradziejowym, choć nastręczają wielu problemów natury metodologicznej, niosą ze sobą ogromny potencjał, jaki tkwi w wieloaspektowym charakterze wniosków, które można przy ich pomocy wyciągnąć. Szersze zastosowanie analiz traseologicznych w badaniach nad uzbrojeniem kultury łużyckiej niewątpliwie pozwoli rzucić nowe światło na przemiany w wojskowości ludów zamieszkujących obszar Polski w epoce brązu i wczesnej epoce żelaza. Z pewnością przyczyni się ono także do lepszego zrozumienia mających swe odbicie w rzeczywistości militarnej przemian socjologicznych, które musiały być również udziałem ludności kultury łużyckiej. 


\section{BIBLIOGRAFIA}

Brandherm D. (2016). Use-wear on Bronze Age halberds: the case of Iberia. W: M. Uckelmann, M. Mödlinger (red.), Bronze Age Warfare: Manufacture and Use of Weaponry (23-38). Oxford: BAR International Series.

Clements J. (2007). The myth of thrusting versus cutting with sword. W: B. Molloy (red.), The Cutting Edge. Studies in Ancient and Medieval Combat (168-176). Stroud: Tempus Publishing Group Limited.

Dolfini A., Crellin R.J. (2016). Metalwork wear analysis: The loss of innocence. Journal of Archaeological Science, 66, 78-87.

Fogel J. (1979). Studia nad uzbrojeniem ludności kultury tużyckiej w dorzeczu Odry $i$ Wisty. Poznań: Wydawnictwo Naukowe UAM.

Gediga B., Hensel Z., Józefowska A. (2018). Zespół mieczy z ciałopalnego cmentarzyska ludności „kultury łużyckiej” w Domasławiu, pow. Wrocław. Przegląd Archeologiczny, 66, 137-175.

Gediga B., Józefowska A. (2018.). Cmentarzysko z epoki żelaza $w$ Domasławiu 10/11/12, powiat wrocławski. Tom 1. Katalog. Wrocław: Wydawnictwo Instytutu Archeologii i Etnologii Polskiej Akademii Nauk.

Gentile V., Gijn van A. (2019). Anatomy of a notch. An indepth experimental investigation and interpretation of combat traces on Bronze Age swords. Journal of Archaeological Science, 105, 130-143.

Gutiérrez Sáez C., Lerma I.M. (2015). Traceology on Metal. Use-Wear Marks on Copper-Based Tools and Weapons. W: J.M. Marreiros, J.F. Gibaja Bao, N. Ferreira Bicho (red.), Use-Wear Methodology on the Analysis of Osseous Industries (171-188). Cham: Springer International Publishing Switzerland, https://doi. org/10.1007/978-3-319-08257-8_8.

Higgins S. (2010). Micro-wear analysis of a middle bronze age sword blade. Records of the Auckland Museum, 47, 193-205.

Horn C., Holstein von I. (2017). Dents in our confidence: The interaction of damage and material properties in interpreting use-wear on copper-alloy weaponry. Journal of Archaeological Science, 81, 90-100.

Horn C., Karck T. (2019). Weapon and tool use during the Nordic Bronze Age. Danish Journal of Archaeology, 8, 1-20.

Kristiansen K. (2002). The tale of sword - swords and swordfighters in Bronze Age Europe. Oxford Journal of Archaeology, 21(4), 319-332.

Mödlinger M. (2007). Herstellung und Verwendung mittelund spätbronzezeitlicher Schwerter aus Österreich. Das Altertum, 52, 101-130.

Mödlinger M. (2016). Ritual object or powerful weapon The usage of Central Europe Bronze Age swords. W: M. Uckelmann, M. Mödlinger (red.), Bronze Age Warfare: Manufacture and Use of Weaponry (153-166). Oxford: BAR International Series.

Molloy B. (2007). What's the bloody point?: Bronze Age swordmanship in Ireland nad Britain. W: B. Molloy (red.), The Cutting Edge. Studies in Ancient and Medieval Combat (90-111). Stroud: Tempus Publishing Group Limited.

Molloy B. (2010). Swords and Swordmanship in the Aegean Bronze Age. American Journal of Archeology, 114, 403-428.

Molloy B. (2016) Use-wear analysis and use-patterns and bronze age swords. W: M. Uckelmann, M. Mödlinger (red.), Bronze Age Warfare: Manufacture and Use of Weaponry (67-85). Oxford: BAR International Series.

O’Flaherty R., Gilchrist M.D., Cowie T. (2016). Ceremonial or deadly serious? New insight into the function of Irish early bronze age halberds. W: M. Uckelmann, M. Mödlinger (red.), Bronze Age Warfare: Manufacture and Use of Weaponry (39-52). Oxford: BAR International Series.

Osgood R. (1998). Warfare in the Late Bronze Age of North Europe. Oxford: BAR International Series. 


\title{
SOME REMARKS ON THE POSSIBLE METHOD OF USE OF A BRONZE SWORD FOUND IN GRAVE NO. 7429 AT THE LUSATIAN CULTURE CREMATION CEMETERY IN DOMASŁAW IN THE LIGHT OF USE-WEAR ANALYSIS.
}

\author{
SUMMARY
}

Detailed research on the function of bronze weapons has undoubtedly become a very important branch of "conflict archaeology" in recent decades. The application of traceology, i.e., the research method involving the analysis of traces left on the surface of archaeological artifacts, has allowed us to verify as erroneous numerous widely prevailing views on the function of prehistoric armament. The research carried out by Kristiansen revealed a lot of damage and traces of repair on the edges of swords from Central Europe dating back to the Bronze Age, a fact which proves their functionality under battlefield conditions. Similar analyses conducted by other researchers on bronze offensive weapons known from other parts of the world led them to the same conclusions. In the case of bronze armaments from Poland, we still confront a meagre amount of research aimed at a thorough understanding of the functions of respective weapons. The studies that have been carried out to date are mainly based on typological divisions having a purely classification character.

The goal of this paper is to present the results of wear analysis of the bronze sword that was found in the cremation cemetery belonging to Lusatian culture in Domasław, dated back to the early Iron Age. The main research task undertaken within the framework of these analyses was to attempt to answer the question whether this sword was used as an effective fighting tool, as well as to attempt to reconstruct the possible technique of its use on the basis of traces observed under the microscope. Despite the fact that in the case of the traceological analyses of the sword from Domasław it was not possible to verify the obtained results via an experiment that would allow for replication of the observed traces, the damage base described in the source literature turned out to be sufficiently rich for drawing reliable conclusions.

Traceological analyses have been carried out by means of digital microscopes at magnifications ranging from 20 to 30 times. All observed traces were documented photographically and then compared with those already recognized on other artifacts. The exceptionally good state of preservation of the Domasław sword allowed the observation of both sides of the sword's blade.

The first of the traces observed was a relatively wide U-shaped notch. This type of damage is usually associated with longer contact between two blades, often combined with twisting movement. In order to determine the origin of such a trace, the presence of fissures in the proximity of the notch, which were visible only on one side of the blade, was important. Presumably, they should to be considered remnants of a repair that involved the grinding of the displaced fragment of the sword's blade.

Another type of damage that was observed during analysis was the waving of the sword edge, which is usually the result of one blade slipping from the other at an acute angle.

Among the identified traces there were also asymmetric indentations and notches surrounded by a part of material displaced as a result of contact with a hard surface. On the sword's fuller surface numerous notches were also observed, ones which probably occurred when blocking an incoming blow with the sword flat.

The amount and type of damage observed by all means allow us to conclude that the sword from Domasław was used as an effective weapon. Deeper reflection on the preferred fighting technique by which this weapon was used has also involved the morphological features of the sword. Placing the center of gravity close to the end of the blade is a solution that works very well while inflicting cuts. Traces found on the sword from Domasław, such as u-shaped notches, seem to be the result of this manner of use. The constructional solution that provided more precise blade control while inflicting this type of blow is the presence of a blunt ricasso, right at the handle, around which the warrior using the sword could wrap his index finger thereby increasing the maneuverability of the weapon itself. Although the arguments cited above suggest that the sword from Domasław was primarily a cutting weapon, it cannot be ruled out that it may also have been used for inflicting thrusts. 
An additional argument bespeaking the full functionality of the Domasław sword is the composition of bronze alloy of which it was made. Tin bronze with the content of $7.51 \% \mathrm{Sn}$ with the addition of lead $(0.91 \% \mathrm{~Pb})$ is characterized by high plasticity, which made the sword quite repairable. Such proportions of the bronze alloy components are not surprising in the context of our knowledge about the production of swords in the Bronze Age and early Iron Age Europe. As metallographic analyses carried out to date have shown, most bronze alloys with a similar composition evince properties that make a sword relatively durable and suitable for potential repair. Traceological analyses of swords made of such bronze alloys have also shown that they were undoubtedly used in combat. It can therefore be concluded that the sword from Domaslaw is not an ex- ception among the bronze offensive weapons known from other areas of Europe.

Wear analyses can of course still be considered a relatively young branch of archaeology. This state of affairs especially concerns research devoted to weapons, but the results of the analyses conducted so far are so promising that further development of this research method can well be expected to broaden our knowledge of the military practices of prehistoric societies. The military activity of the people of Lusatian culture is no exception in this respect and the application of the traceological method to the research into other finds of armament attributed to this culture may shed completely new light on warfare and the militaria of the Bronze Age and Early Iron Age in today's Poland.

Otrzymano (Received): 1.04.2020; zrecenzowano (Revised): 29.07.2020; zaakceptowano (Accepted): 13.08.2020

Adres Autora:

\author{
Mgr Jakub Witowski \\ Instytut Archeologii \\ Uniwersytet Wrocławski \\ ul. Szewska 48; 50-139 Wrocław \\ e-mail: jakub.witowski2@uwr.edu.pl
}

(iD https://orcid.org/0000-0002-7353-1502 
